in male, plainly evident in female; median carina distinct on metazona, obsolete or but faintly visible on prozona; disk a uniform dark brown in two specimens, the prozona blotched with fuscous in the remaining two; the lateral lobes with a piceous band on their upper two-thirds which extends to metazona, then setting in again on meso-pleurite continues about half the length of the abdomen, gradually fading posteriorly; bordered below on cheek and prozona with pallid, or testaceous in female, (ivory white in life, as is also the meta-pleurite). Tegmina uniform dark wood brown, narrowly separated dorsally, a very little shorter than pronotum, oval in outline, breadth $I_{\frac{1}{2}}$ in length with apex subangulate; broader in female, breadth $1 \frac{1}{4}$ in length with apex rounded. Hind femora light testaceous on upper and outer faces, faintly and obliquely bifasciate with fuscous; yellowish on inner and lower faces with the fuscous bars plainer on the former, geniculation blackish. Hind tibiae pale red, the spines black, ten in outer series. Extremity of male abdomen entire, moderately recurved; supra-anal plate triangular, a little longer than broad, the sides rather high, the median sulcus narrow, shallow, and terminating near the middle of the plate; the furcula consist of a pair of short, flattish triangular projections of the inner corners of the divided lateral halves of the last dorsal segment and overlie the basal portion of the median sulcus; cerci styliform, a little shorter than the supra-anal plate, tapering strongly on basal half, gradually on apical half to the rather blunt apex.

Female, moderately robust, with colors duller than in the male.

Average measurements: Length of body, male, $15 \mathrm{~mm}$., female, $20 \mathrm{~mm}$.; antennae, male, $7 \mathrm{~mm}$., female, $8 \mathrm{~mm}$; tegmina, male, $4 \mathrm{~mm}$., female, $5 \mathrm{~mm}$.; hind femora, male, $9.5 \mathrm{~mm}$., female, I I mm. Three males, one female, La Salle Island, Michigan, August I 7, I 897 .

Two or three males of islandicus were taken from shady places about the borders of the clearing, in which huroni was found, but the remaining six or eight secured were found along the margins of a narrow pathway which led through the dense woods down the eastern slope of the island. They would leap from the pathway into the mosses and liverworts bordering its sides, and there remain quiet while the intruder passed by. None were found at a distance of more than ten feet from this pathway, though especial search was made for them.

\title{
SOME NEW BYTHOSCOPINAE WITH NOTES ON OTHERS.
}

BY C. F. BAKER, ALA. POLYTECHNIC INST. AUBURN, ALA.

Bythoscopus fagi Fh.

This is as good a species as any, and occurs sparingly throughout the northeast. It is small, length about $4 \mathrm{~mm}$., the females rufous throughout, paler below, the males with the elytra much darker. The last ventral segment is slightly shorter than preceding and very broadly bilobed. I have a number of males and females from the vicinity of Washington, D. C., and have seen others from New York and Massachusetts. 
Bythoscopus variabilis $\mathrm{Fh}$. var. coloradensis $n$. var.

I give this name to a form found in northern Colorado which cannot be separated structurally from variabilis, though the color is quite distinctive. The head, pronotum, scutel, and clavus basally, are yellow. Vertex with two small black spots. The pronotum has the depressed area behind each eye rufous. The sides of front, sternum, legs, and abdomen, are rufous. The elytra are rufescent with two hyaline spots on disc.

Described from numerous specimens taken in the foothills west of Fort Collins, June ${ }^{5} 5^{\text {th }}$ to August 4th and at Forrester's Ranch on the Upper Laramie River in August. In both localities pruni was common with it. This variety was recorded in the Prelim. List Hemip. Colo. as fenestratus. I do not know that fenestratus, the type of which I have studied, has ever been found in Colorado.

The most important work yet to be done among our Jassoid insects, is the careful breeding of the various forms in large numbers. This is especially true among the Bythoscopids and Typhlocybids. In Bythosopus, Pediopsis, and Idiocerus, such work, properly done, will be fraught with the most important results.

\section{Bythoscopus truncatus n. sp.}

Female. Length $4.5 \mathrm{~mm}$. Color clear rufous, venter darker laterally. Legs pale yellowish, fore femora rufous, middle and hind femora piceous. Elytra subhyaline, narrow costal and apical margins, and two irregularly transverse bands fuscous. Last ventral segment as long as preceding, truncate posteriorly. Face finely rugoso-punctate. Vertex, and pronotum anteriorly, coarsely irregularly punctured, the former with a faint median callosity. Pronotum posteriorly rather coarsely transversely rugose.

Described from a single female, collected by myself at the Michigan Agricultural College in I888. At that time Mr. Van Duzee called this sobrius, but later settled that name on a very different form which I have since received from the northeast in numbers.

\section{Agallia bigeloviae Baker.}

The type of this species represents a small pale form. Farther west it becomes larger and frequently darker, when superficially it more closely resembles sanguinolenta. But the form of the last ventral segment of the female is distinctive. There are specimens in the Nat'l Museum from Death Valley and the Panamint Mts., collected by $\mathrm{Mr}$. Koebele, and one from Los Angeles, collected by Mr. Coquillett.

Agallia sanguinolenta Prov. var. inconspicua $\mathrm{n}$. var.

There are in the National Museum two specimens of a very small form, pale yellowish throughout except two 
black spots on vertex, and with hyaline elytra, which have the external genitals almost identical with those of sanguinnolenta. They were collected at Los Angeles by Mr. Coquillett. I have also specimens from Arizona collected by Dr. Kunze. It will require the study of large series from various localities to decide whether it be really a form of sanguinolenta.

\section{Agallia californica n. sp.}

Length 3-3.25. Intermediate between uhleri and sanguinolenta, the former of which it closely resembles in coloration. Aciculation of pronotum finer than in uhleri, and punctuation on vertex medially finer, sometimes scarcely distinguishable. Hind margin of last ventral segment in female trisinuate, the median notch of varying size but always very small. The plates of the male are rectangular, black at tips, and stand in nearly the same plane, the apical margins often nearly in one straight line; outer apical angles obtuse, inner acute and minutely more or less produced. The valve is short and very broadly evenly rounded.

Described from several specimens in the Nat'l Museum, from Los Angeles (Coquillett), one from Nevada Co., Cal. (Koebele), and several from Tehachapi, Cal. (Morse). The form of genitals readily separate this from a large series of sanguinolentus and $u$ hleri from Colorado and various parts of the East. It has a shorter-winged form also found at Los Angeles, and collected by Mr. Koebele in Placer Co., Cal.

\section{Agallia lyrata n. sp.}

Male. Length 3.5. Very similar to californicus but larger, the color and sculpturing nearly the same as in that species. Valve very short, shorter than in californicus, and broadly rounded. Plates very long, outer margins towards base strongly outwardly bent, beyond strongly narrowed and running parallel sided to the black rectangularly truncate tips; taken altogether, distinctly lyrate.

This species has been collected by Mr. Koebele in Nevada Co., Cal. Prof. Morse found it also at Wawona and Tehachapi, Cal. Apparently a very distinct species of the uhleri group.

\section{Agallia heydei n. sp.}

Form of A. constricta but larger. Length, male 3.75 , of female $4.25 \mathrm{~mm}$.

Female: Face a fourteenth longer than wide. Front narrower than in 4-notatus, strongly constricted below the antennae. Vertex about as long at the middle as at the eyes. Pronotum not quite twice wider than long, length more than four times that of the vertex. Last ventral segment suddenly constricted at middle, beyond this evenly bulging, then rapidly narrowing to a shallowly notched apex; a semicircular depressed area on either side of apical half.

Color nearly as in 4-notatus. Brownish with lighter areas. Antennal cavities and spots including the ocelli, black. Vertex with two large black spots midway between median line and eyes. Pronotum with two large black spots on posterior half. Elytra with light veins on a brownish field. Sternum and basal portion of venter blackish.

Male: Plates with sides evenly incurved to middle; then enlarged towards the evenly rounded, very obtuse tips.

Described from many specimens col- 
lected in the State of Vera Cruz, Mexico, by Rev. H. Th. Heyde. This is one of many interesting things which Mr. Heyde has turned up in Mexico, and I take pleasure in dedicating it to him. It is nearest constricta and 4notata, but differs from either in the structure of face and genitals.

\section{Agallia mexicana n. sp.}

More slender than constricta which it resembles. Length, female 3.5 , male 3.25 $\mathrm{mm}$.

Face about a twentieth longer than wide. Front proportioned as in heydei, strongly constricted below the antennae. Vertex as long at middle as at eyes. Pronotal width once and nine tenths the length, the length three and a half times that of the vertex. Elytra proportionally narrower than in constricta. Last ventral segment with hind margin slightly concave, its disc entirely lacking the characteristic depressed areas of constricta.

Color as in the paler form of constricta, except that the spots on vertex and pronotum are much larger, and the elytra are clearer gray.

Male: Valves narrowing to a slender but obtuse tip, the sides at about half their length more or less distinctly very obtusely angulated.

Described from many specimens collected in the State of Vera Cruz, Mexico by Rev. H. Th. Heyde. This belongs to the 4-notata group, which includes 4-notata, constricta and heydei. Of this it is nearest constricta, but differs as described above.

\section{Agallia anomala n. sp.}

Form of novella but smaller. Length of female, $3.5 \mathrm{~mm}$. Face a twelfth longer than wide. Front long and narrow, sides evenly curved. Vertex shorter at middle than at eyes, margin back of eyes broad, as in novella. Pronotal width once and three fourths the length, the length about five times that of the vertex. Last ventral segment broadly shallowly notched, the two lobes thus formed, evenly rounded.

Color pale greenish gray, sternum, legs, and venter pale yellowish. Face rufous, lighter towards margins; clypeus and lower part of front, antennae cavities, two diagonal streaks between the ocelli and front, and a spot extending inward from eyes and including ocellus, deep black. Vertex pale yellowish with two small dots between the median line and the eyes, and a large black spot at inner angle of eye. Pronotum very finely but distinctly shagreened, with three brown points, one at apex and two on disc. Elytra with dark fuscous clouding in outer claval cell, two anteapical cells and third apical cell.

State of Vera Cruz, Mexico (Rev. H. Th. Heyde). This peculiar form is an interesting addition to the novella group.

\section{Agallia producta n. sp.}

Resembling anomala. Length of male and female, $3.5 \mathrm{~mm}$.

Female: Face a twelfth longer then wide. Front broad, sides evenly curved from antennae to clypeus. Vertex of nearly the same form as in anomala and novella. Pronotal width about once and two thirds the length, the length five and a half times that of the vertex. Hind margin of last ventral segment medially strongly produced to an obtuse point, lateral angles broadly rounded.

Differing in color from anomala as follows: Face pale yellowish, minute dots adjoining the ocelli inwardly, antennae 
cavities and spots on propleurae black. Medium spots on vertex much larger. Basal angles of scutel and two dots in front of the transverse line, black. Elytra without fuscous areas.

Male: Plates long, about two and a half times as long as total breadth at base, sides concave on basal two thirds, thence from the obtuse angle thus formed strongly narrowed to the tips. Differs in color from the female as follows: Head and scutel other than markings bright yellow. Spots at ocelli larger and including ocelli. Vertex with a large median black spot at base. Pronotum with two points at apex and a median line, blackish. Veins of elytra somewhat darker towards base.

State of Vera Cruz, Mexico (Rev. H. Th. Heyde). This species belongs to the novella group but is very distinct from either novella or anomala.

\title{
THREE NEW COCCIDAE OF THE SUBFAMILY IDIASPINAE.
}

\author{
BY T. D. A. COCKERELL, MEsilla, NEW MEXiCo.
}

Aspidiotus (Diaspidiotus) coniferarum, n. sp. - 9 scale I I-3 mm. diam., circular or nearly so, rather convex (about as in rapax), white, with the red-brown exuviae to one side of the middle. First skin usually exposed. A white ventral film.

$q$ yellowish-brown, of ordinary form; no circumgenital grouped glands; median lobes close together, large, broad and low, rather like those of spurcatus; second lobe low and broad, subobsolete but marked by the wide depression between it and the first lobe, it resembles the same lobe in betulae, but is longer; third lobe a rounded prominence, hardly a lobe, as in betulae; three spine-like plates (gland-hairs) in the first interlobular interval; three, larger, behind the second lobe; these branch more or less, the last especially having two long lateral branches; a long and strong spine just beyond the third lobe, and another similar spine on the margin a good distance beyond. The two pairs of interlobular incisions are very well-formed and are like those of betulae. Anal orifice large, and only a short distance from the hind end. Lateral portions of caudal plate with numerous filiform (spermatozoon-like) glands.
The embryonic larvae, in the body of the $q$, are remarkably large, and have the legs and antennae well tormed.

Hab. - Organ Mts., New Mexico. Detected by Mr. H. Casad on a small pine tree (doubtless Pinus ponderosa v. scopulorum) which was brought to Mesilla and used as a Christmas tree. The scales occur plentifully on the upper part of the trunk. A. coniferarum is more like certain European species. than any found in America; it probably occurs far to the north, and belongs to the boreal or subboreal fauna, reaching its most southern limit, like some other species, in New Mexico. It is infested by a fungus.

Pseudoparlatoria noacki, n. sp. $-q$ scale I 2-3 mm. diam., flat, or very slightly convex, circular or nearly so; stained with light coffee-brown, except the margins, which remain white, sometimes the whole scale being whitish ; exuviae central to sublateral, rather large, exposed, first skin near margin of second, both skins orange-brown, varying to very pale greenish yellow, the first skin sometimes greenish with a yellow spot at each end. A white ventral film. I scale smaller, broad-oval, flat, semitransparent white; larval skin large, slightly greenish, 

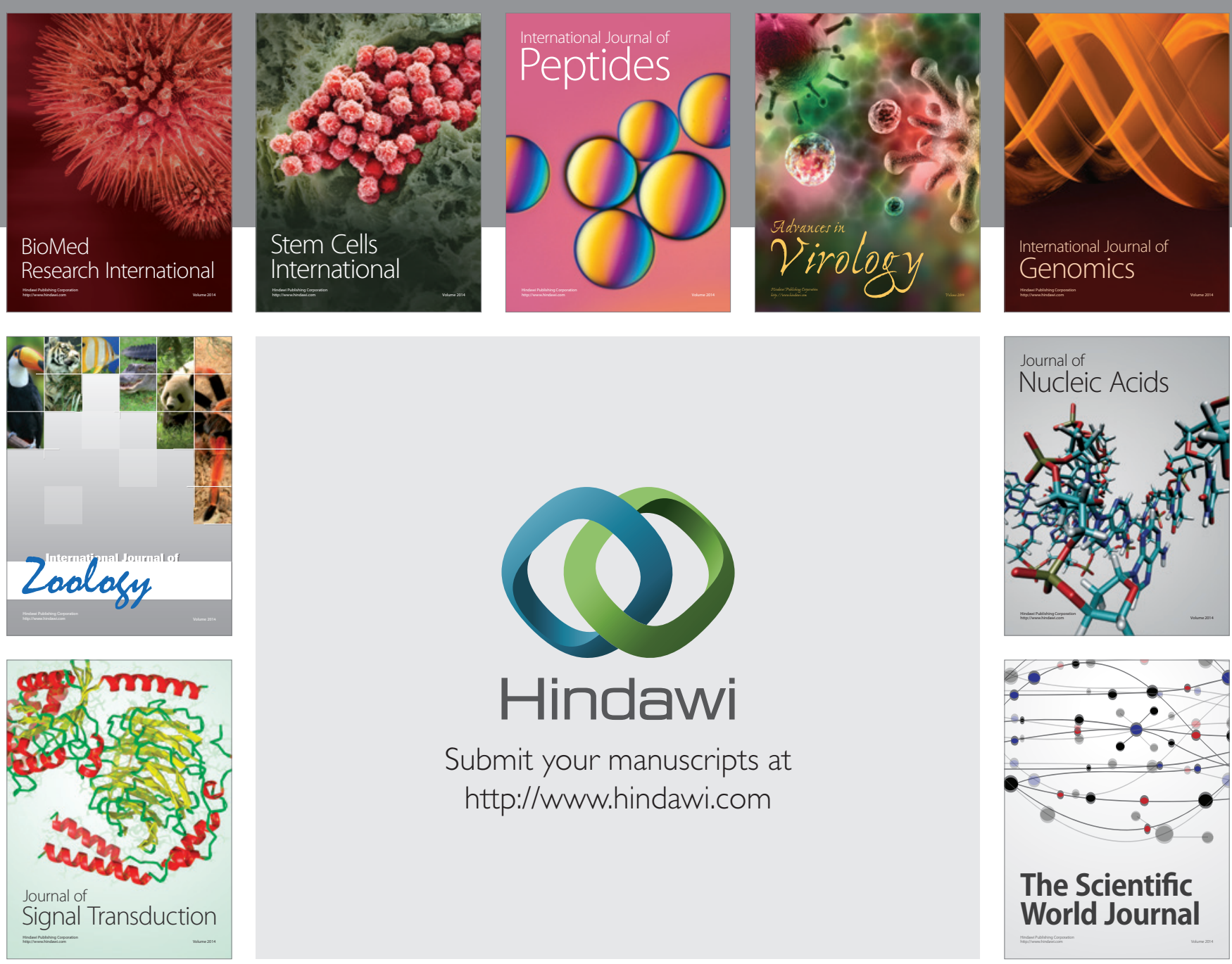

Submit your manuscripts at

http://www.hindawi.com
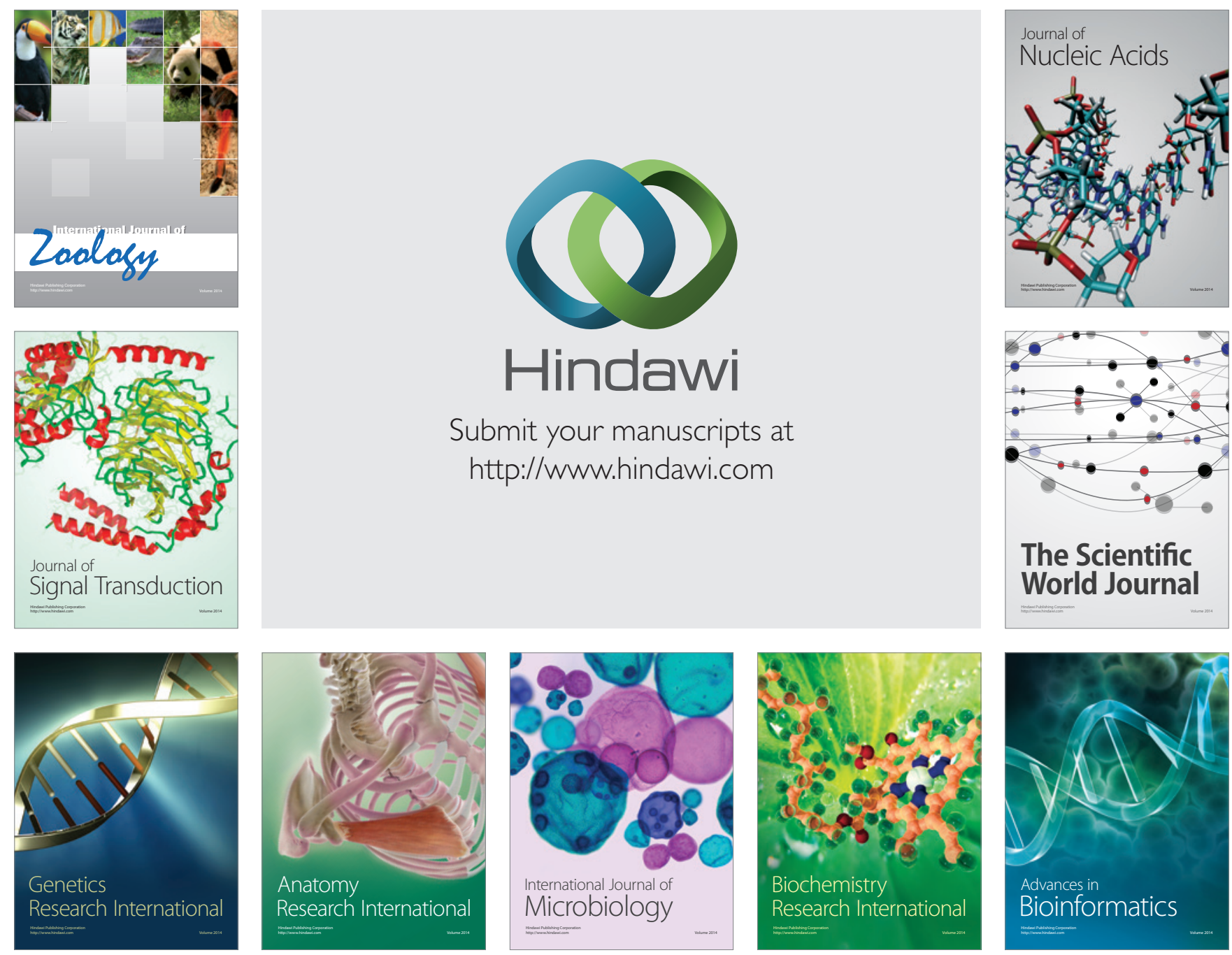

The Scientific World Journal
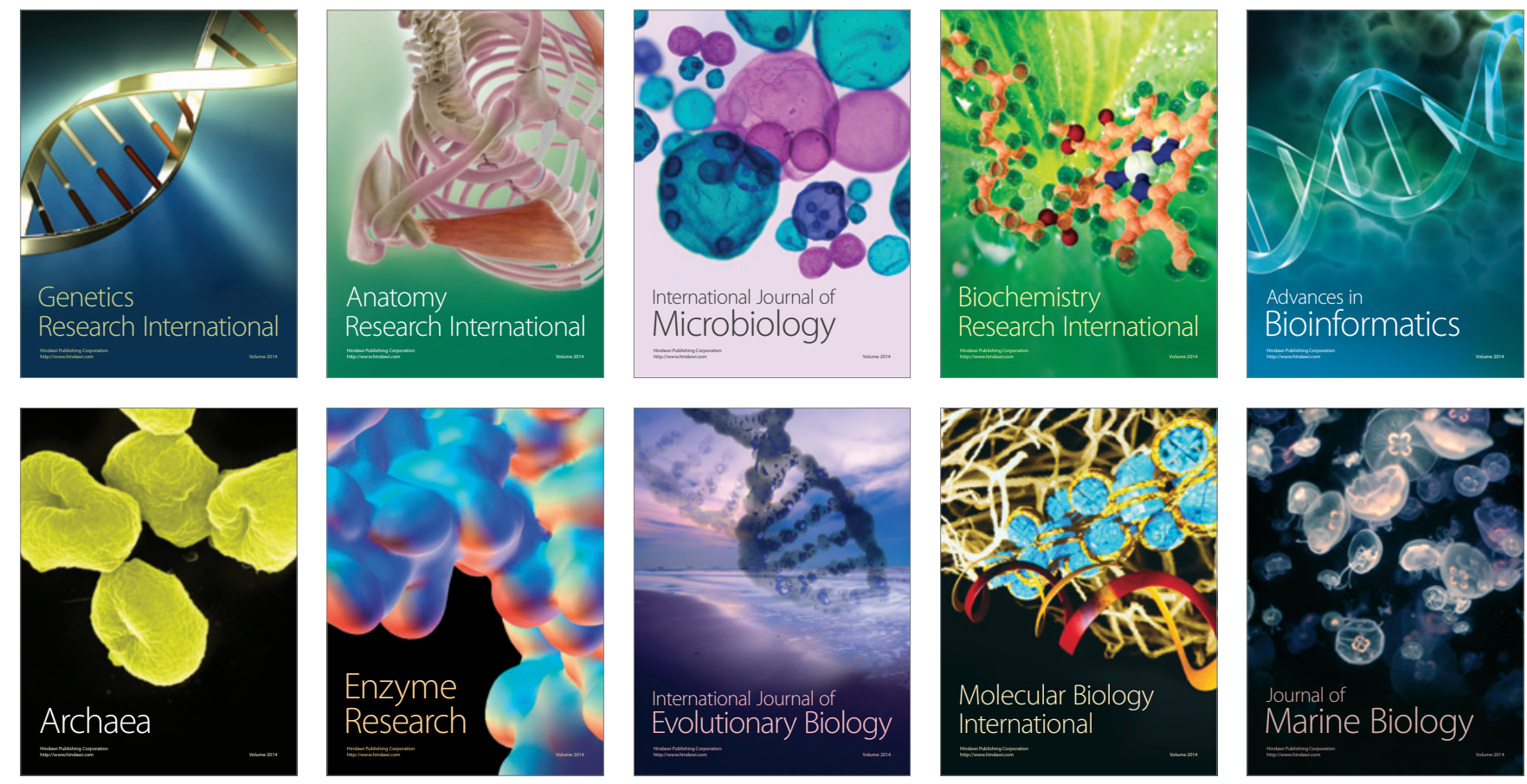